Kamińska K., Wptyw ordoliberalizmu na rozwój polityki konkurencji w RFN i Unii Europejskiej, „Ekonomia i Prawo”, Polszakiewicz B., Boehlke J. (red.), Tom XII, nr 2/2013, ss. 233-243. DOI: http://dx.doi.org/10.12775/EiP.2013.018

\title{
WPŁYW ORDOLIBERALIZMU NA ROZWÓJ POLITYKI KONKURENCJI W RFN I UNII EUROPEJSKIEJ
}

\section{STRESZCZENIE}

Doktryna ordoliberalna i jej zalecenia odnośnie do polityki konkurencji stanowią oryginalny niemiecki wkład w rozwój nauk ekonomicznych i prawniczych. Teoria ta wywarła ogromny wpływ na rozwój niemieckiego prawodawstwa antymonopolowego, a także przyczyniła się do powstania traktatów rzymskich, w tym unijnego prawa konkurencji. Pomimo różnych zastrzeżeń, jakie kierowane są pod jej adresem, nadal wywiera ona wpływ na kształt prawa europejskiego poprzez wykorzystywanie jej niektórych definicji i reguł w orzecznictwie sądów unijnych oraz praktyce decyzyjnej Komisji Europejskiej.

Słowa kluczowe: ordoliberalizm, polityka konkurencji

Klasyfikacja JEL: B25, K21, P16

\section{IMPACT OF THE ORDOLIBERAL THEORY ON THE DEVELOPMENT OF COMPETITION POLICY IN GERMANY AND THE EUROPEAN UNION}

\section{SUMMARY}

Ordoliberal doctrine and its recommendations on competition policy is an original German contribution to the development of economics and law. This theory has had

* Katarzyna Kamińska, Uniwersytet Mikołaja Kopernika, Wydział Nauk Ekonomicznych i Zarządzania, Katedra Ekonomii, tel.: +48 503316 305, e-mail: kkam@mat.umk.pl. 
an enormous impact on the development of German anti-trust legislation, and also contributed to the Treaties of Rome, including EU competition law. Despite various claims, which are directed towards it still has an impact on the shape of European law by using some of ordoliberal definitions and rules in the courts of the EU and the European Commission's decision-making practice.

Keywords: ordoliberal theory, competition policy

JEL Classification: B25, K21, P16

\section{WSTĘP}

Literatura ekonomiczna sporo uwagi poświęca teorii ordoliberalnej, podkreślając jej wpływ na kształtowanie się systemu gospodarczego współczesnych Niemiec. Sukces tej teorii był jednak nie tyle wynikiem osiągnięć samych ekonomistów niemieckich, ile efektem ścisłej współpracy pomiędzy nimi a niemieckimi prawnikami. Opracowane przez nich oryginalne rozwiązania instytucjonalno-prawne, w tym szczególnie z zakresu prawa konkurencji, umożliwiły praktyczną realizację części ekonomicznych postulatów ordoliberalizmu. Rozwiązania te okazały się na tyle obiecujące, że stały się obiektem naśladownictwa. Celem artykułu jest przedstawienie stopnia, w jakim teoria ordoliberalna ukształtowała podstawy niemieckiej i unijnej polityki konkurencji.

\section{WOLNA KONKURENCJA W TEORII ORDOLIBERALNEJ}

Od momentu powstania ordoliberalnej szkoły ekonomii i prawa głównym przedmiotem jej zainteresowania był problem optymalnego rozmiaru władzy ekonomicznej w państwie. Czołowy przedstawiciel tego nurtu - Walter Eucken poświęcił temu zagadnieniu sporo swojej uwagi ${ }^{1}$. W swoich pracach starał się znaleźć odpowiedź na pytania dotyczące możliwości skutecznego oddziaływania ekonomii na gospodarkę, sposobu wpływania i przeciwstawiania się partiom politycznym i grupom ekonomicznego nacisku. Zasadniczą siłą porządkującą w gospodarce jest, według niego, państwo, które jak napisał w jednej ze swoich najsłynniejszych prac - Grundsätze der Wirtschaftspolitik ${ }^{2}$, powinno $\mathrm{w}$ ramach prowadzonej polityki w pierwszej kolejności rozbijać gru-

${ }^{1} \mathrm{Na}$ temat ekonomistów i prawników należących do tego nurtu patrz szerzej: Ch. Watrin, Die Tradition freiheitlicher und sozialer Politik, [w:] Ludwig-Erhard-Stiftung (red.), Soziale Marktwirtschaft als historische Weichenstellung. Bewertung und Ausblicke, ST - Verlag, Bonn, 1996, s. 3-23.

${ }^{2}$ W. Eucken, Die Grundsätze der Wirtschaftspolitik, Mohr Siebeck, Tübingen 2004. 
py dominujące w gospodarce, występujące chociażby w postaci karteli, trustów, koncernów, związków zawodowych pracowników i pracodawców, bądź ograniczyć ich funkcje. Grupy te według niego nie tylko miały tendencje do ograniczania konkurencji, lecz również próbowały wpływać na politykę gospodarczą w celu realizacji własnych korzyści. Eucken zauważa, że grupy lobbystów dążą do zmiany ram procesu gospodarowania, m.in. poprzez państwowe ustalanie cen, ograniczenie zezwoleń na prowadzenie działalności gospodarczej czy zakazów importu³.

Ordoliberalny prawnik - Franz Böhm w pracy pt. Das Problem der privaten Macht postulował potrzebę wzmocnienia państwa od strony prawnej. Szczególne znaczenie przypisywał wprowadzeniu prawodawstwa gwarantującego wolną konkurencję oraz planowy ład w poszczególnych obszarach gospodarki. Jego zdaniem pozostawienie gospodarki samej sobie przyczyni się w nieunikniony sposób do rozwoju monopoli ${ }^{4}$. Państwo, które będzie lekceważyć swoją funkcję w tym zakresie, spowoduje pojawienie się nierównowagi w gospodarce oraz licznych zakłóceń, które ostatecznie osłabią jego pozycję. Eucken proponował prowadzenie przez państwo zdecydowanej, konfrontującej polityki oraz świadome powstrzymywanie się przez nie od rozdzielania przywilejów ${ }^{5}$. Rozwiązaniem miał być taki wybór formy rządzenia państwem, który miałby zapewniać indywidualną wolność wszystkim podmiotom gospodarczym przez swobodę konkurowania na rynkach. Uczestnicy gry rynkowej nie powinni mieć żadnego wpływu na reguły rządzące rynkiem, a ustalony porządek gospodarczy nie powinien zagrażać demokracji i istniejącemu prawu ${ }^{6}$. Punktem odniesienia dla myśli ordoliberalnej jest w tym zakresie model konkurencji doskonałej, pełnej, której istnienie i funkcjonowanie powinno być chronione prawem przez państwo silne, niezależne i dbające jednoznacznie o ład wolnokonkurencyjny ${ }^{7}$. Wolna konkurencja, w zamyśle niemieckich ekonomistów, miała

${ }^{3}$ Por. W. Eucken, Die Grundlagen der Nationalökonomie, 9. Auflage, Springer-Verlag, Berlin -Heidelberg-New York-London-Paris-Tokyo-Hong Kong 1989, s. 158.

${ }^{4}$ Por. F. Böhm, Das Problem der privaten Macht, [w:] E.J. Mestmäcker (red.), Reden und Schriften. Über die Ordnung einer freien Gesellschaft, einer freien Wirtschaft und über die Wiedergutmachung, Verlag C. F. Müller, Karlsruhe 1960, s. 43-45.

${ }^{5}$ Patrz szerzej: W. Eucken, Die Grundsätze..., op. cit., s. 334-336.

${ }^{6} \mathrm{Na}$ ten temat pisze także: T.T. Kaczmarek, Zasady porzadku w gospodarce rynkowej. Rola państwa, Difin, Warszawa 2004 oraz F. Böhm, Die Bedeutung der Wirtschaftsordnung für die politische Verfassung, [w:] F. Böhm, Reden und Schriften. Über die Ordnung einer freien Gesellschaf, Verlag C. F. Müller, Karlsruhe 1960, s. 62.

7 Eucken na gruncie teoretycznym stworzył model tego typu ładu. Warunkiem jego urzeczywistnienia była realizacja przez państwo w polityce gospodarczej siedmiu zasad konstytuujących i czterech regulujących, por. W. Eucken, Die Grundsätze..., op. cit., s. 254 - 303. W skład zasad regulujących wchodził: sprawny system cen konkurencji doskonałej, stabilizacja waluto- 
zapewnić szeroki zakres wolności, m.in. do inicjatywy indywidualnej, tworzenia nowych dóbr, procedur, rynków, wolności gospodarczej, czy wyboru pomiędzy różnymi alternatywami. W celu jej ochrony przed grupami interesów ordoliberałowie zaproponowali utworzenie specjalnej instytucji - urzędu antymonopolowego, który kontrolowałby $\mathrm{z}$ ramienia państwa przestrzeganie prawa antymonopolowego. Była to oryginalna i nowatorska idea, ponieważ w tamtym okresie w żadnym kraju nie funkcjonowała tego typu instytucja ${ }^{8}$.

Postawa antymonopolistyczna w Niemczech ma swoje historyczne korzenie $\mathrm{w}$ niechęci wobec monopoli skompromitowanych współpracą $\mathrm{z}$ reżimem faszystowskim. Dzięki wykorzystywaniu siły ekonomicznej tych przedsiębiorstw, szczególnie z sektora przemysłu ciężkiego - węglowego i stalowego - oraz przekształcenia tej siły w siłę polityczną, reżim faszystowski mógł się rozwijać. Konstrukcja ówczesnego ładu prawnego nie pozwalała ani na zapobieżenie ani na zatrzymaniu tego rozwoju' ${ }^{9}$ Innym źródłem antymonopolistycznej postawy była obawa, że wzmocnienie pozycji monopoli zagrozi interesom klasy średniej, do której skierowany był ordoliberalizm, oraz spowoduje zanik konkurencji.

Niemieccy ekonomiści i prawnicy bardzo kategorycznie podkreślali konieczność istnienia i ochrony wolnej konkurencji. Prof. E.J. Mestmäcker, wybitny znawca prawa europejskiego i były asystent F. Böhma, stwierdził w jednym z wywiadów, że chociaż Eucken wywarł ogromny ideologiczny wpływ na powstanie traktatów rzymskich, to jednak kwestia rozumienia przez niego postulatu ochrony wolnej konkurencji może dziś wydawać się kontrowersyjna. Na jej potwierdzenie przytacza historię zapisaną przez ucznia Euckena - Leonarda Mikscha. Eucken zapytany podobno przez innego ordoliberała - Wilhelma Röpke - co należy zrobić w sytuacji, gdy koncern Coca-Cola, stosujący reklamę sugerującą, zagraża istnieniu szwajcarskiego przemysłu produkującego soki owocowe - odparł, że należy zakazać koncernowi tego typu reklam. Inną propozycją Euckena było zakazanie elektryczności w celu ochrony przemysłu produkującego świeczki ${ }^{10}$. Przykłady te pokazują, że wolność gospodarcza i wol-

wa, zagwarantowanie dla wszystkich otwartości rynków, istnienie własności prywatnej, swoboda zawierania umów, materialna odpowiedzialność za skutki swoich działań i stabilna polityka gospodarcza. Natomiast zasady regulujące akcentowały konieczność kontroli i nadzoru monopoli przez państwo, prowadzenie polityki dochodowej, racjonalnego rachunku ekonomicznego i zapobieganie anormalnym zachowaniom podaży.

8 Por. D.J. Gerber, Constitutionalizing the Economy: German Neo-Liberalism, Competition Law and the „New Europe”, 41 Am. J. Comp. L. 1994, t. 42, s. 66.

${ }^{9}$ Ibidem, s. 42-43.

${ }^{10}$ Die Aktualität Euckens, Ein Gespräch zwischen Ernst-Joachim Mestmäcker und Walter Oswalt, [w:] W. Eucken, Die Grundsätzte der Wirtschaftspolitik, op. cit., s. 403. 
ność do konkurowania może mieć na tyle istotne znaczenie dla ordoliberałów, że mająca je urzeczywistnić ochrona procesu konkurencji powinna podlegać ochronie nawet wtedy, gdy prowadzi to do nieefektywności ekonomicznej.

Obserwacja zmian, jakie zachodzą w gospodarkach kapitalistycznych XXI wieku, głównie w zakresie stopnia ich monopolizacji, nasuwa bardzo poważną wątpliwość, czy i w jakim stopniu model ten jest nadal adekwatny do opisu ich funkcjonowania ${ }^{11}$. Próba prowadzenia polityki gospodarczej ściśle na podstawie jej wymagań może nastręczać wielu trudności, gdyż nawet sam Eucken był zdania, że jedynie w ustroju wolnokonkurencyjnym jest możliwa kontrola i nadzór monopoli przez państwo. Wynika z tego, że w obecnej sytuacji polityka konkurencji, prowadzona w duchu ordoliberalnym może okazać się nie w pełni skuteczna w realizacji przewidzianych dla niej celów lub może prowadzić do przypisywania większej wartości celom o charakterze humanistycznym czy politycznym, a nie ekonomicznym.

\section{ORDOLIBERALIZM \\ A PODSTAWY NIEMIECKIEJ I UNIJNEJ POLITYKI KONKURENCJI}

Niemiecka Republika Federalna jest przykładem państwa, w którym próbowano realizować pewne elementy wspólne z euckenowską koncepcją ładu konkurencyjnego. Było to najbardziej widoczne w okresie, gdy Ludwig Erhard był ministrem gospodarki, a później kanclerzem Niemiec Zachodnich ${ }^{12}$. W tym okresie zaczęto nazywać niemiecki model gospodarczy społeczną gospodarką rynkową. Erhard uważał, że społeczna gospodarka rynkowa wywodzi się z połączenia podstawowych elementów wolnej gospodarki przedsiębiorstw $\mathrm{z}$ wolną konkurencją i swobodnym kształtowaniem się cen na rynkach oraz wolnym i odpowiedzialnym kształtowaniem życia obywateli i respektowania zasad ładu gospodarczego ${ }^{13}$.W książce Dobrobyt dla wszystkich wskazywał, że wolna konkurencja jest również środkiem do osiągnięcia i zapewnienia dobrobytu każdemu obywatelowi ${ }^{14}$. Ma ona zatem kształtować społeczeństwo,

11 Por. J. K. Galbraith, Ekonomia a cele spoteczne, Państwowe Wydawnictwo Naukowe, Warszawa 1979 , s. 55.

12 W latach 1949 - 63 Erhard sprawował funkcję ministra gospodarki, a w latach 1963 - 66 był kanclerzem RFN.

${ }^{13}$ Por. L. Erhard, Selbstverantwortliche Vorsorge für die sozialen Lebensrisiken, [w:] K. Hohmann (red.), Ludwig Erhard. Gedanken aus fünf Jahrzehnten, ECON Verlag, Düsseldorf/Wien/ New York 1988, s. 461.

${ }^{14}$ L. Erhard, Dobrobyt dla wszystkich, Polskie Towarzystwo Ekonomiczne, Warszawa 2012, s. $18-19$. 
zapewniać wszystkim równe szanse, a nie być jedynie celem samym w sobie. Jej istnienie jest niezbędne przy rozwiązywaniu problemów społecznych, które stają się częścią większej kwestii, jaką jest dostatecznie wolny ład gospodar$\mathrm{czy}^{15}$. Konkurencja nie może być jednak pozostawiona sama sobie, ale wymaga koordynacji ze strony silnego państwa.

Postulaty szkoły ordoliberalnej stworzyły koncepcyjne podstawy rozwiązań przyjętych $\mathrm{w}$ niemieckiej ustawie przeciw ograniczeniom konkurencji - Gesetz gegen Wettbewerbschränkungen (GWB) z $1957^{16}$. Ustawę tę traktuje się jako jeden $z$ najważniejszych filarów społecznej gospodarki rynkowej ${ }^{17}$.

Dyskusje nad kształtem prawa antykartelowego w RFN trwały prawie 8 lat i budziły wiele kontrowersji ${ }^{18}$. Zakończono je 27 lipca 1957 roku uchwaleniem ustawy przeciw ograniczaniu konkurencji. Zasadniczym jej celem byto zabezpieczenie i wspieranie zdecentralizowanej struktury gospodarki. Wy-

15 W. Eucken, Die soziale Frage, Edgar Salin, Synopsis, wydanie okolicznościowe dla Alfreda Webera, Heidelberg 1948, s. 131.

${ }^{16}$ Gesetz gegen Wettberwerbschränkungen (GWB), 1957 Bundesgesetzblatt [BGB1.] 1081.

17 Zyskała ona nawet nazwę Konstytucji spotecznej gospodarki rynkowej, por. H. Lampert, Die Soziale Marktwirtschaft In der Bundesrepublik Deutschland, „Aus Politik und Zeitgeschichte” 1988, nr B 17, s. 89. Drugą podstawą prawną polityki konkurencji jest w Niemczech ustawa przeciwko nieuczciwej konkurencji - Gesetz gegen den unlauteren Wettberwerb (UWG) uchwalona 27 maja 1896 roku, znowelizowana 7 czerwca 1909 roku. Jej celem było: zapewnienie uczciwości konkurencji, ochrony jej wydajności i walki z konkurencją, która nie polegała na wydajności. $Z$ jednej strony chroniła ona konkurenta przed nieuczciwymi działaniami innych konkurentów, a $z$ drugiej strony jej zadaniem była ochrona także kontrahentów umowy po przeciwnej stronie rynku. Ustawa ta w sposób jednoznaczny zabroniła podejmowania działań skierowanych przeciwko dobrym zwyczajom. Osoby, które naruszyły tę zasadę, miały zostać ukarane odszkodowaniem. Ostatnia nowelizacja miała miejsce 8 lipca 2004 roku.

18 Początkowo odbywały się one w ramach specjalnej komisji pod przewodnictwem prawników - Paula Jostena i Franza Böhma, a ich efektem był napisany w 1949 roku ordoliberalny projekt ustawy o zapewnieniu konkurencji i o urzędzie antymonopolowym - Entwurf zu einem Gesetz zur Sicherung des Leistungswettbewerbs und zu einem Gesetz über das Monopolamt, nazywany Josten Draft. Tekst tego projektu wywołał wiele kontrowersji, zwłaszcza dlatego, że zalecał wprowadzenie zakazu karteli i nadawał b. szerokie kompetencje urzędowi antymonopolowemu. Instytucja ta miała być niezależna od Ministerstwa Gospodarki, a jej zadania miały się sprowadzać do śledzenia, oraz karania tych, którzy przekraczali prawo Projekt ten, ze względu na restrykcyjność swoich propozycji został odrzucony. Patrz szerzej: L. Murach - Brand, Antitrust auf Deutsch. Der Einfluß der amerikanischer Allienten auf das Gesetz gegen Wettbewerbschränkungen nach 1945, „Beiträge zur Rechtsgeschichte des 20. Jahrhunderts" nr 43, Mohr Siebieck, Tübingen 2004, s. 107 i dalsze. Pod naciskiem m.in. Adenauera i Związku Przemysłu Niemieckiego (BDI) Erhard musiał nieco złagodzić przedłożony projekt. Debata na temat prawa antykartelowego ujawniła duże różnice zdań występujące pomiędzy zaangażowanymi stronami, co wynikało z różnych wizji przyszłych reform, a także modelu gospodarczego. 
różniała ona trzy podstawowe typy ograniczania konkurencji przez prywatne podmioty, przypisując im odpowiednie metody postępowania ${ }^{19}$ :

a. koordynacja zachowań - zakaz karteli;

b. koncentracja - kontrola fuzji, połączeń;

c. nadużycia pozycji rynkowej - nadzór nad nadużyciami przedsiębiorstw dominujących na rynku.

Tekst ustawy przewidywał generalny zakaz tworzenia karteli wraz z precyzyjnie określonymi wyjątkami $(\S \S 2-8)^{20}$. Wyjątki te obejmowały wiele różnych typów karteli, których ilość z biegiem czasu powiększała się. Wśród nich można było wyróżnić chociażby kartele wyspecjalizowane, średniej wielkości kartele, kartele racjonalizatorskie, importowe, eksportowe czy strukturalne kartele kryzysowe. Powstała lista wyjątków była wynikiem kompromisu rządu z niemieckim przemysłem. Starano się również o to by zredukować potencjalny negatywny wpływ prawa na konkurencyjność niemieckich przedsiębiorstw. Kompromis ten był jednak rozczarowaniem dla ordoliberałów, chociaż samo uchwalenie tej ustawy uważane było za jedno $\mathrm{z}$ ich największych zwycięstw politycznych ${ }^{21}$. W literaturze przedmiotu można spotkać opinie, że wspomniane wyjątki osłabiły skuteczność tej ustawy w walce z ponowną koncentracją przemysłu niemieckiego $\mathrm{w}$ latach 50 . i na początku lat $60 .{ }^{22}$

Ustawa GWB weszła w życie 1 stycznia 1958 roku, a na jej mocy powołano do istnienia organy nadzorujące wykonanie ustawy - Federalny Urząd ds. Karteli (Bundeskartellamt), a ponadto krajowe urzędy ds. Karteli (Landeskartellämte). W późniejszych okresach ośmiokrotnie ją nowelizowano (po raz pierwszy w 1973 roku, a ostatni w 2012 roku). Duża liczba nowelizacji spowodowała stopniowe odejście od jej głównego celu, jakim było zagwarantowanie istnienia wolnej konkurencji, na rzecz innych celów, a wysiłki Erharda i jego zwolenników, zmierzające do podniesienia znaczenia wolnej konkurencji, wywołały falę krytyki tego prawa. Przyczyna krytyki tkwiła w użytym sformułowaniu w $\$ 1$, gdyż zakaz dotyczył klasycznych form kartelu, które były w tamtym okresie w Niemczech powszechnie spotykane ${ }^{23}$. Konieczność harmonizacji prawa niemieckiego $\mathrm{z}$ antymonopolowym prawem Unii Europej-

19 I. Schmidt, Wettberverbspolitik und Kartellrecht, 8. Auflage, Lucius\&Lucius, UTB, Stuttgart 2005, s. 170 i dalsze.

${ }^{20}$ Stan na rok 1998.

${ }^{21}$ Por. D.J. Gerber, Constitutionalizing..., op. cit., s. 65-66.

22 Por. J. C. van Hook, Rebuilding Germany. The Creation of the Social Market Economy 1945-1957, Cambridge University Press, Cambridge 2004, s. 234 i dalsze.

${ }_{23}$ Por. D.J. Gerber, Law and Competition in Twentieth Century Europe: Protecting Prometheus, Oxford University Press, Oxford 2001, s. 296. 
skiej spowodowała usunięcie $\mathrm{z}$ ustawy, $\mathrm{z}$ dniem 1.06.2005 roku $\S \S 4-8$, co zmniejszało w teorii liczbę typów karteli niepodlegających zakazowi z $\$ 1^{24}$.

GWB wywarła duży wpływ na ustawodawstwo antymonopolowe Unii Europejskiej ${ }^{25}$. W latach 50. zeszłego wieku była ona postrzegana jako pierwszy, nowoczesny, najbardziej zaawansowanym intelektualnie tego typu akt prawny w powojennej Europie ${ }^{26}$. Jej zasadnicze założenia legły u podstaw unijnego zakazu nadużycia pozycji dominującej - art. 81 i art. 82 traktatów rzymskich ${ }^{27}$. Założenia ordoliberalne oddziaływały nie tylko na treść zakazu, ale nade wszystko na kształtujące prawo orzecznictwo sądów unijnych oraz praktykę decyzyjną Komisji Europejskiej. Znalazło to wyraz w poszczególnych regułach (instytucjach) prawnych, które dotyczyły stosowania art. 102 TFUE. Wiele z tych reguł obowiązuje do dziś. Wśród nich można wymienić ${ }^{28}$ : kryteria ustalania dominacji przywiązujące zasadnicze znaczenie dla wielkości udziałów rynkowych, doktrynę „szczególnej odpowiedzialności” ciążącą na przedsiębiorstwach dominujących, formalne podejście do niektórych praktyk rynkowych przedsiębiorstw dominujących oraz relatywnie szeroki zakres nadużyć o charakterze praktyk nieuczciwych.

Treść art. 102 TFUE jest postrzegana jako odzwierciedlenie ordoliberalnego postulatu, zgodnie $\mathrm{z}$ którym prawo konkurencji powinno służyć ochronie procesu konkurowania przed zakłóceniami nie tylko ze strony państwa, ale

${ }^{24}$ Chociaż raport komisji monopolowej za okres 2008/2009 noszący sugestywny tytuł - Więcej konkurencji, mniej wyjątków potwierdził istnienie problemu zbyt wielu wyjątków od zakazu tworzenia karteli. Zwracał on także uwagę na wzrost koncentracji największych podmiotów gospodarczych i wskazywał na pilną potrzebę zwiększenia konkurencji w niektórych sektorach gospodarki (usługi telekomunikacyjne, sprzedaż leków i środków medycznych), por. Der Achtzehntes Hauptgutachten der Monopolkommission gemäß § 44 Abs. 1 Satz 1 GWB $-2008 / 2009$.

${ }^{25} \mathrm{~W}$ literaturze znajduje się wiele potwierdzeń tezy, że idee ordoliberalne wywarły wpływ na proces jednoczenia się Europy. Oprócz wpływu na prawo konkurencji, również na ideę wspólnego rynku i cały szereg instytucji UE, por. D.J. Gerber, Law and Competition ..., s. 263. Czołowi niemieccy reprezentanci zaangażowani w budowę Wspólnot Europejskich byli blisko związani z ordoliberalizmem, np. Walter Hallstein, pierwszy prezydent Komisji Europejskiej. Większość jego poglądów na temat roli prawa w kształtowaniu przyszłych instytucji Europy było odbiciem idei pochodzących z tego nurtu, por. D.J. Gerber, Law and Competition ..., s. 263-265.

${ }^{26}$ Data wejścia w życie GWB nieprzypadkowo pokrywała się z datą traktatów rzymskich - 01.01.1958 roku.

27 Por. D. Hildebrand, The European School in EC Competition Law, W. Comp. 2002, t. 25, nr 1, s. 3, cyt. za: K. Kohutek, Praktyki wykluczające przedsiębiorstw dominujących. Prawidtowość i stosowalność regut prawa konkurencji, Wolters Kluwer Polska, Warszawa 2012, s. 63, D.J. Gerber, Constitutionalizing..., op. cit., s. 73. Obecnie jest to artykuł 101 i 102 Traktatu o funkcjonowaniu Unii Europejskiej, TFUE, Dz. Urz. U.E.C 306 z 17.12 2007, wersja skonsolidowana Dz. Urz. U. E. C 83 z 30.03.2010, s. 88-89.

${ }^{28}$ Podaję za: K. Kohutek, op. cit., s. 63 i dalsze. 
także ze strony samych przedsiębiorstw, stając się przez to istotnym mechanizmem chroniącym wolność gospodarczą ${ }^{29}$. Zwłaszcza w orzecznictwie unijnym wolność gospodarcza i wolność konkurowania są rozumiane w sensie ordoliberalnym ${ }^{30}$. Kładzie ono nacisk na zapobieganie, zwalczanie powstawania lub kumulowanie prywatnej władzy rynkowej, która może stanowić zagrożenie dla tych wartości ${ }^{31}$. Beneficjentami tak pojmowanych wolności są klienci dominanta, jak i jego konkurenci. Zakazywanie praktyki dominantów uznawano jako ograniczanie klientom wyboru w postaci swobodnego dostępu do rynku zaopatrzenia lub jako ograniczanie konkurentom dostępu do klienteli, co można interpretować jako naruszenie ordoliberalnej wolności konkurowania. Niezwykła waga, jaką przypisywano ochronie tych wartości uwidoczniła się już w pierwszym raporcie Komisji, który dotyczył polityki konkurencji. Konkurencja została tam uznana jako najlepszy stymulator działalności gospodarczej, gwarantujący wszystkim możliwie najszerszą wolność działania ${ }^{32}$.

W literaturze prawniczej podkreśla się, że odwoływanie się ordoliberalizmu do wartości pozaekonomicznych (humanistycznych i politycznych) powoduje pojawianie się kolizji pomiędzy tymi wartościami a argumentami postulowanymi na gruncie ekonomicznego podejścia do instytucji zakazu nadużycia pozycji dominującej. Można w związku z tym spotkać opinie, że zakaz z art. 102 TFUE funkcjonuje w niejednolitych i nieprzejrzystych ramach aksjologicznych $^{33}$. Strukturalno-wolnościowe użycie zakazu nie zawsze bywa też korzystne dla dobrobytu konsumenta. Jak podaje literatura przedmiotu, w obrocie handlowym często podejmowane są praktyki zdatne do wykluczenia konkurentów z rynku, ale mające neutralny lub wręcz korzystny wpływ na sytuację ekonomiczną konsumentów, czego przykładem są chociażby obniżki cenowe, rabaty, czy sprzedaż wiązana praktykowane przez takie firmy jak Microsoft ${ }^{34}$.

\section{ZAKOŃCZENIE}

Zmiany zachodzące w gospodarkach kapitalistycznych w XXI wieku powodują, że niektóre teorie ekonomiczne wydają się coraz mniej przydatne do

\footnotetext{
${ }^{29}$ Ibidem, s. 65-66.

30 Ordoliberalna wolność jest definiowana jako swoboda uczestniczenia w rynku w sposób niezagrożony przez siłę innych przedsiębiorstw, por. ibidem, s. 76.

31 Ibidem, s. 75.

32 Chodzi o pkt 11 Pierwszego Raportu Rocznego dotyczacego Polityki Konkurencji z 1971 roku, Bruksela - Luksemburg, kwiecień 1972.

33 Ibidem, s. 57.

${ }^{34}$ Ibidem, s. 93-94.
} 
opisu ich funkcjonowania. Teoria ordoliberalna, poprzez odwoływanie się do modelu konkurencji doskonałej i wartości humanistyczno-politycznych, może być współcześnie postrzegana jako nieaktualna czy proponująca podmiotom działania nieefektywne ekonomicznie. Stwierdzenie to zawiera jedynie część prawdy. Wybitne osiągnięcia ordoliberalizmu na polu nauk prawniczych na trwałe powiązały ją $\mathrm{z}$ niemieckim i unijnym prawem konkurencji, a koncepcja urzędu antymonopolowego stała się inspiracją do utworzenia tego typu instytucji w różnych krajach. Pomimo swoich słabych stron i pewnej niejednoznaczności interpretacyjnej również orzecznictwo sądów unijnych i praktyka decyzyjna Komisji Europejskiej nadal preferuje ordoliberalną definicję wolności gospodarczej i wolności do konkurowania, przez co doktryna ta nadal wpływa na instytucjonalno-prawny kształt zarówno RFN, jak i Unii Europejskiej.

\section{BIBLIOGRAFIA}

Böhm F., Das Problem der privaten Macht, [w:] E.J. Mestmäcker (red.), Reden und Schriften. Über die Ordnung einer freien Gesellschaft, einer freien Wirtschaft und über die Wiedergutmachung, Verlag C. F. Müller, Karlsruhe 1960.

Böhm F., Die Bedeutung der Wirtschaftsordnung für die politische Verfassung, [w:] F. Böhm, Reden und Schriften. Über die Ordnung einer freien Gesellschaf, Erhard L., Selbstverantwortliche Vorsorge für die sozialen Lebensrisiken, [w:] K. Hohmann (red.), Ludwig Erhard. Gedanken aus fünf Jahrzehnten, ECON Verlag, Düsseldorf/Wien/New York 1988.

Erhard L., Dobrobyt dla wszystkich, Polskie Towarzystwo Ekonomiczne, Warszawa 2012.

Eucken W., Die Grundlagen der Nationalökonomie, 9. Auflage, Springer-Verlag, Berlin -Heidelberg-New York-London-Paris-Tokyo-Hong Kong 1989, http://dx.doi.or g/10.1007\%2F978-3-642-61337-1.

Eucken W., Die Grundsätze der Wirtschaftspolitik, Mohr Siebeck, Tübingen 2004.

Eucken W., Die soziale Frage, Edgar Salin, Synopsis, wydanie okolicznościowe dla Alfreda Webera, Heidelberg 1948.

Galbraith J.K., Ekonomia a cele spoteczne, Państwowe Wydawnictwo Naukowe, Warszawa 1979.

Gerber D.J., Constitutionalizing the Economy: German Neo-Liberalism, Competition

Law and the „New Europe”, 41 Am. J. Comp. L. 1994, t. 42, http://dx.doi. org/10.2307\%2F840727.

Gerber D. J., Law and Competition in Twentieth Century Europe: Protecting Prometheus, Oxford University Press, Oxford 2001. 
Gesetz gegen Wettbewerbschränkungen (GWB), 1957 Bundesgesetzblatt [BGB1.] 1081. Hildebrand D., The European School in EC Competition Law, W. Comp. 2002, t. 25, nr 1.

Hook van J.C., Rebuilding Germany. The Creation of the Social Market Economy 1945-1957, Cambridge University Press, Cambridge 2004, http://dx.doi. org/10.1017\%2FCBO9780511511936.

Kaczmarek T.T., Zasady porzadku w gospodarce rynkowej. Rola państwa, Difin, Warszawa 2004.

Kohutek K., Praktyki wykluczające przedsiębiorstw dominujacych. Prawidtowośc i stosowalność regut prawa konkurencji, Wolters Kluwer Polska, Warszawa 2012.

Lampert H., Die Soziale Marktwirtschaft In der Bundesrepublik Deutschland, „Aus Politik und Zeitgeschichte" 1988, nr B 17.

Mączyńska E., Pysz P. (red.), Spoteczna gospodarka rynkowa. Idee i możliwości praktycznego wykorzystania w Polsce, PTE, Warszawa 2003.

Murach -Brand L., Antitrust auf Deutsch. Der Einfluß der amerikanischer Allienten auf das Gesetz gegen Wettberwerbschränkungen nach 1945, „Beiträge zur Rechtsgeschichte des 20. Jahrhunderts" nr 43, Mohr Siebieck, Tübingen 2004.

Nicholls A.J., Freedom with responsibility: the social market economy in Germany 19181963, Oxford University Press 1994.

Pysz P., Spoteczna gospodarka rynkowa. Ordoliberalna koncepcja polityki gospodarczej, $\mathrm{Wy}-$ dawnictwo Naukowe PWN, Warszawa 2008.

Röpke W., Gesellschaftskrisis der Gegenwart, Eugen Rentsch Verlag, Erlenbach - Zürich 1942.

Rüstow A., Zwischen Kapitalismus und Kommunismus, „ORDO - Jahrbuch für die Ordnung von Wirtschaft und Gesellschaft", Bd. 2, Helmut Küpper Verlag, Godesberg 1949.

Watrin Ch., Die Tradition freiheitlicher und sozialer Politik, [w:] Ludwig-Erhard-Stiftung (red.), Soziale Marktwirtschaft als historische Weichenstellung. Bewertung und Ausblicke, ST - Verlag, Bonn, 1996.

Schmidt I., Wettbewerbspolitik und Kartellrecht, 8. Auflage, Lucius\&Lucius, UTB, Stuttgart 2005, http://dx.doi.org/10.1524\%2F9783486715224.

Traktat o funkcjonowaniu Unii Europejskiej, TFUE, Dz. Urz. U.E.C 306 z 17.12 2007, wersja skonsolidowana Dz. Urz. U. E. C 83 z 30.03.2010. 
